\section{The economics of terrorism: a synopsis}

Fernanda Llussá and José Tavares

$\mathrm{T}$ he number of economics of terrorism studies has increased dramatically since 11 September 2001. Yet in spite of the renewed attention to the field, much remains to be clarified and integrated with what we already know from the economics of terrorism. In this article, we map what we believe are the most important results of this literature, highlighting key papers we deem representative of our state of knowledge, and organizing the literature into their macro versus micro and empirical versus theoretical aspects. ${ }^{1}$

We adopt Enders and Sandler's (2002) view of terrorism as "the premeditated use or threat of use of extra-normal violence or brutality by sub-national groups to obtain a political, religious, or ideological objective through intimidation of a huge audience, usually not directly involved with the policymaking that the terrorists seek to influence.” In economic studies of terrorism, this is the most frequently used definition. Its three main elements are: (a) the use of extreme violence, (b) the "underground" nature of terrorist acts, individuals, and organizations, and (c) publicity, i.e., the intended effect on a broad audience, possibly through the media.

A topical summary of the terrorism literature

We organize the subject matter around seven topics, namely (1) the measurement of terrorist activity, (2) the nature of terrorists, (3) the utility cost of terrorism, (4) the impact of terrorism on aggregate output, (5) terrorism and specific sectors of activity, (6) terrorism and economic policy, and (7) counter-terrorism. These cover the universe of terrorism topics to which economists have devoted their effort. For each, we identify the most relevant papers and point to the main conclusions.

The measurement of terrorist activity

Terrorist attacks are relatively rare and extreme events. The number of attacks is highly volatile over time and across countries (Enders and Sandler, 2002). ${ }^{2}$ Evidence of cyclical patterns are observed, with increased incidence during economic downturns (Im, et al., 1987; Enders and Sandler, 1995, 2000; Blomberg, Hess, and Weerapana, 2004b) and around elections (Berrebi and Klor, 2004; Brauer, et al., 2004). Over time terrorist attacks have became more lethal (Enders and Sandler, 2000; Sandler and Enders, 2004), a possible consequence of a change both in terrorist motivations, from ideological to religious-based, and method, e.g., the increased use of suicide attackers (Berman and Laitin, 2005). In addition, since the 1967 ArabIsraeli war, attacks are markedly transnational in nature. ${ }^{3}$

The targets of terrorism are frequently in rich countries, the United States being the most often targeted state (Blomberg, et al., 2004a, 2004c; Enders and Sandler, 2002), yet it remains unclear whether democracies are likelier targets (see Blomberg, et al., 2004a, for a yes; Tavares, 2004, for a no; and Abadie, 2004, for a non-monotonic answer to the question).

The most widely used data sets regarding the measurement of terrorist activity are those by Mickolus and associates - Mickolus (1980, 1982), Mickolus and Fleming (2003), Mickolus, et al. (1989, 1993) - and the data set from the International Policy Institute for Counter-Terrorism (2003). Other data sets, usually with narrow dissemination, either cover disaggregated data or are specialized in nature, based for instance on sectoral or individual information. However, most data sets are built from counts of actual terrorist attacks or victims which ignores the very relevant indirect and psychological costs of terrorism. ${ }^{4}$

The nature of terrorists

Explanations for the emergence of terrorist groups range from those based on individual or group behavior to aggregate correlates. Although generalizations are extremely risky at the current stage of research, the dominant view suggests that the support for terrorist acts is not associated with lower educational or economic status (Krueger and Maleckova, 2003; Berrebi, 2003; Schelling, 1991). ${ }^{5}$ As the presence of suicide actors dramatically illustrates, non-orthodox explanations for terrorism may be required. ${ }^{6}$ These are provided by the work of Wintrobe $(2001,2006)$ on extreme tradeoffs, Hardin (1995) on group identity, Ferrero (2005) on the use of social sanctions, and Berman (2003) and Berman and Laitin (2005) on club good theory. Individual hatred toward specific groups or nations can emerge from misinformation and manipulation by political leaders (Glaeser, 2005; Charney and Yakatan, 2005) who can enhance follower loyalty by promoting violence (Epstein and Gang, 2004).

At the aggregate level, different studies view terrorism as the result of tensions including the availability of new resources with modernization (Crenshaw, 1981; Aziz, 1995) or the rise of religious-based fundamentalism (Crenshaw, 1981). Terrorism may be a substitute for other forms of political conflict in the internal fight over resources (Garfinkel, 2004; Blomberg, et al., 2004c) and terrorist acts are part of a signaling game where governments are uninformed of terrorists' strengths (Lapan and Sandler, 1993). Terrorism, it has been argued, has also been used in the international arena as a foreign policy tool (O’Brien, 1996). 


\section{The utility cost of terrorism}

Certainly, terrorist acts have an adverse impact on individual utility and on the economy. However, its association with extreme harm and uncertainty suggest that terrorism's utility cost goes beyond the direct and immediate damage. Terrorism entails costs linked to what has been named a "non-rational” evaluation of risk on the part of individuals, i.e., a decrease in utility well beyond the computable expectation of losses. The perception of this cost may be associated with an outcome-independent negative impact of "fear and loathing" that greatly exceeds the "objective" discounted harm (Becker and Rubinstein, 2004; Sunstein, 2003; Viscusi and Zeckhauser, 2003). ${ }^{7}$ Despite, or because of its "non-rational" nature, this perceived cost can be quite substantial, as suggested in Frey, et al. (2004).

\section{The impact of terrorism on aggregate output}

A large number of studies focus on measuring the economy-wide impact of terrorist attacks. They conclude that the direct cost to output is relatively small, smaller than the cost of internal conflict, external war, or natural disasters. Nonetheless, for specific populations, regions, and sectors the adverse effects can be very large.

A considerable number of articles on the economics of terrorism concentrates on the output consequences of terrorist events. The main conclusion is that the direct cost to output seems relatively low and short-term (Hobijn, 2002; International Monetary Fund, 2001; Navarro and Spencer, 2001, who analyze the physical and human losses). Terrorist attacks do reduce economic growth although the estimated impact is smaller than that of violent internal conflict and external war (Blomberg, et al., 2004a) or natural disasters (Tavares, 2004). Nonetheless, high and persistent levels of terror (Eckstein and Tsiddon, 2004) or terror concentrated in specific regions (Abadie and Gardeazabal, 2003; World Bank, 2002, 2003) have a considerable impact. Although less targeted, poorer countries suffer more from attacks (Blomberg, et al., 2004a, on poorer countries; World Bank, 2002, 2003, on Israel versus the Palestine territories). ${ }^{8}$ There is evidence that democratic countries are more resilient to attacks (Tavares, 2004).

An alternative way to look at the effect of terror on aggregate output is through its impact on the value of stocks of different companies. Here researchers have found evidence that the impact is relatively short-term and may decrease over time (Choudhry, 2003; Chen and Siems, 2004; Eldor and Melnick, 2004) probably due to efficient diversification which diminishes the influence of risk on particular stocks.

\section{Terrorism and specific sectors of activity}

The economics literature provides ample evidence that terrorism is associated with significant differential impacts on specific sectors of the economy. Such a severe shock, concentrated in time, is likely to affect consumption and investment in response to a willingness to free resources for other uses. In fact, there are noticeable decreases in consumption after terror attacks (Eckstein and Tsiddon, 2004; Fielding, 2003a) and decreases in investment (Eckstein and Tsiddon, 2004; Blomberg, et al., 2004a; Fielding, 2003b), the latter a consequence of a crowding-out effect in response to increases in public spending. International capital and trade flows are also likely to decrease (Abadie and Gardeazabal, 2005; Enders and Sandler, 1996, for capital flows; for trade, see Walkenhorst and Dihel, 2002; Nitsch and Schumacher, 2004). ${ }^{9}$

Tourism and airline demand, due to their specific vulnerability to attacks and consumer sentiment, have attracted special research attention. The consensus points to a clear negative impact on tourism and airline demand (Drakos and Kutan, 2003; Enders, et al., 1992; Enders and Sandler, 1991, 1996; Sloboda, 2003; Fleischer and Buccola, 2002, on tourism; Drakos, 2004; Ito and Lee, 2004, on airline demand). The concentration of economic and governmental activities and the large population density of urban areas suggests a greater vulnerability to terrorism. If this view holds, terrorism can be viewed as a tax on cities. However, the estimates by most authors point to a very limited cost, especially in the long-run (Bram, et al., 2002; Glaeser and Shapiro, 2002; Harrigan and Martin, 2002; Mills, 2002; and Rossi-Hansberg, 2003).

Given the association of terrorism with risk in general, and the dramatic revisions in risk profile faced by economic activities, the insurance industry is likely to be affected, either positively or negatively, by terrorist attack. ${ }^{10}$ In addition, changes in exposure may highlight market imperfections in the industry. There is evidence that the stock of insurance companies does react to increased terrorist risk (Cummins, et al., 2003). ${ }^{11}$ Berrebi and Klor (2005) show strong evidence of a differential and positive impact on defense and security industries in Israel in the aftermath of terror attacks. $^{12}$

Terrorism and economic policy

Terrorism can affect fiscal and monetary policy in the same way as any other unexpected shock would, or as policymaking responds endogenously to terrorist events. The increase in public spending in response to additional security needs is likely to be small (Lenain, et al., 2002; Gupta, et al., 2004; and Hobijn, 2002) and probably with little impact on budget deficits (Eichenbaum and Fisher, 2004; and Wildasin, 2002).$^{13}$ As to the reaction of the payments system in the face of an attack, Lacker (2004) shows how the Federal Reserve credit extension after 11 September increased the supply of banks' balances and decisively preempted the emergence of a payments crisis after the terrorist attack. 


\section{Countering terrorism}

Counter-terrorism is probably the most policy-relevant issue on the economics of what can be done to reduce the incidence and impact of terror acts. Two basic options are available: to counter terrorism by force (the "stick") or by increasing the opportunity cost of terrorism (the "carrot”), making targets less attractive or adjusting media coverage to diminish its attractiveness. ${ }^{14}$ In thinking about counter-terrorism it is realistic to acknowledge beforehand that complete eradication of terrorist activity is unlikely, not only because of imperfect information and cost asymmetry, which gives terrorist groups a strategic advantage, but also due to continuous innovation by both sides to the conflict. ${ }^{15}$

As terrorists substitute among means, targets, and across time, counter-

terrorist strategies beyond deterrence, such as comprehensive multilateral coordination, must be developed and applied.

The literature provides evidence that terrorists substitute among means, targets, and across time (Im, et al., 1987, for substitution over time and targets; Garfinkel, 2004; Blomberg, et al., 2004c, for substitution with other forms of violence). This ability on the part of terrorists suggests the use of a portfolio of anti-terrorist measures (Enders and Sandler, 2004; Frey, 2004). So far, deterrence has been the main response of states to terrorist organizations although it might not be the right strategy since it induces escalation. ${ }^{16}$ Credible non-negotiating policies are also important (Sandler and Enders, 2004) but time inconsistency is a major issue and there is a high risk of default (Lapan and Sandler, 1993). Economic sanctions are also used frequently but are probably ineffective. ${ }^{17}$ An important mechanism is active limitation of terrorist funding through better regulation (Fitzgerald, 2004). Frey and Luechinger (2003, 2004) and Frey (2004) argue forcefully for decreasing benefits or raising the opportunity cost, rather than the material cost of attacks. In contrast, some states tolerate the activities of terrorist organizations in their territory in exchange for no direct harm and at the expense of other nations - a dominant strategy, according to Lee (1988) - which points to the desirability of multilateral coordination and institutions. On an optimistic note, evidence suggests that people realize the complexity of terrorism and are ready to accept more flexible policy responses (Downes and Hoffman, 1993), including in cases involving hostage taking (Shambaugh and Josiger, 2004).

One plausible response to terrorism is adjusting how political institutions (Wilkinson, 2001) or legal institutions function (Garoupa, et al., 2005; Enders, et al., 1990). Mueller (2004) argues that it is necessary instead to strengthen democratic institutions and increase citizens' understanding and support for those institutions. Other options include decentralizing political institutions to decrease the attractiveness of targets (Frey and Luechinger, 2003).

\section{Concluding remarks}

We presented a brief overview of the economics literature on terrorism. Evidently, this is an expanding field that addresses very diverse issues using varied research methodologies. In Table 1 we classify the papers as to their macro versus micro and empirical versus theoretical emphasis. Although subjective, this classification makes clear where additional contributions can be made: most of the existing studies are of an empirical nature and examine the consequences of terrorist attacks at the aggregate level and in specific sectors of economic activity. In the case of the micro-based studies, the mix of papers is more balanced. In Table 2 we present a list of twelve papers we think ably summarize what is now known on economics and terrorism. These twelve papers are suggestive of the broad range of questions addressed and the progress made, constituting a very useful introduction to the literature.

Sadly, terrorism will probably rank high on the political agenda for years to come. Understanding the motivations of terrorists and terrorist groups and diminishing the occurrence and the effects of violence must be a key element in the response to terrorism. This is only possible if we extend our knowledge on the intrinsic nature of terrorist phenomena by collecting new data to answer the remaining questions, thus decreasing the extent of our ignorance of its causes and consequences. In this effort, the role of research in economics, as surveyed in this paper, is likely to remain central. 
The Economics of Peace and Security Journal, ISSN 1749-852X

(c) www.epsjournal.org.uk - Vol. 2, No. 1 (2007)

\section{Table 1: The economics of terrorism literature in 4 boxes}

Mostly theoretical ( $\mathrm{n}=31)$

Becker and Rubinstein (2004)

Berman (2003)

Berman and Laitin (2005)

Enders and Sandler (2004)

Epstein and Gang (2004)

Ferrero (2005)

Garoupa, Klick, and Parisi (2005)

Glaeser (2005)

Lapan and Sandler (1993)

Lee (1988)

Sunstein (2003)

Wintrobe (2001)

Woo (2002)

$(\mathrm{n}=13)$

Abadie and Gardeazabal (2005)

Aziz (1995)

Berrebi and Klor (2004)

Blomberg, Hess, and Weerapana (2004c)

Crenshaw (1981)

Eckstein and Tsiddon (2004)

Enders and Sandler (1995)

Enders, Sandler, and Cauley (1990)

Fitzgerald (2004)

Frey and Luechinger (2004)

Frey and Luechinger (2003)

Garfinkel (2004)

Harrigan and Martin (2002)

Lenain and Koen (2002)

Mills (2002)

Mueller (2004)

OECD (2002)

Rossi-Hansberg (2003)

$(\mathrm{n}=18)$
Mostly empirical $(\mathrm{n}=52)$

Berman and Stepanyan (2004)

Berrebi (2003)

Charney and Yakatan (2005)

Krueger and Maleckova (2003)

Pape (2003)

Frey, Luechinger, and Stutzer (2004)

Viscusi and Zeckhauser (2003)

Downes-Le Guin and Hoffman (1993)

Shambaugh and Josiger (2004)

$(\mathrm{n}=9)$

Abadie (2004)

Abadie and Gardeazabal (2003)

Berrebi and Klor (2005)

Blomberg, Hess, and Orphanides (2004a)

Blomberg, Hess, and Weerapana (2004b)

Bram, Haughwout, and Orr (2002)

Brauer, Gómez-Sorzano, and Sethuraman (2004)

Brown, Cummins, Lewis, and Wei (2004)

Brück and Wickström (2004)

Chalk, Hoffman, Reville, and Kasupski (2005)

Chen and Siems (2004)

Choudhry (2003)

Cummins and Lewis (2003)

Drakos (2004)

Drakos and Kutan (2003)

Eichenbaum and Fisher (2004)

Eldor and Melnick (2004)

Enders and Sandler (2002)

Enders and Sandler (2000)

Enders and Sandler (1991)

Enders and Sandler (1996)

Enders, Sandler, and Parise (1992)

$(n=43)$
Fielding (2003a)

Fielding (2003b)

Fleischer and Buccola (2002)

Glaeser and Shapiro (2002)

Gupta, Clements, Bhattacharya, and Chakravarti (2004) Hobijn (2002)

Im, Cauley, and Sandler (1987)

International Monetary Fund (2001)

Ito and Lee (2004)

Kunreuther, Michel-Kerjan, and Porter (2003)

Lacker (2004)

Navarro and Spencer (2001)

Nitsch and Schumacher (2004)

O'Brien (1996)

Sandler and Enders (2004)

Sloboda (2003)

Tavares (2004)

Walkenhorst and Dihel (2002)

Wildasin (2002)

World Bank (2002)

World Bank (2003) 


\section{Table 2: Twelve economic papers on terrorism}

Paper

Abadie, Alberto and Javier Gardeazabal (2003) "The

Economic Costs of Conflict: A Case Study of the Basque Country." American Economic Review

Berman, E. and Laitin, D. (2005) "Hard Targets: Theory and Evidence on Suicide Attacks.” National Bureau of Economic Research

Eckstein, Zvi and Daniel Tsiddon (2004) "Macroeconomic

Consequences of Terror: Theory and the Case of Israel.” Journal of Monetary Economics

Enders, Walter and Todd Sandler (2002) "Patterns of Transnational Terrorism, 1970-1999:

Alternative Time-Series

Estimates." International Studies Quarterly

Frey, Bruno S. and Simon Luechinger (2003) "How to Fight Terrorism: Alternatives to

Deterrence." Defense and Peace Economics

Krueger, Alan B. and Jitka Maleckova (2003) "Education, Poverty and Terrorism: Is There a Causal Connection?” Journal of Economic Perspectives

\section{Questions addressed}

- What is the impact of terrorism in a region submitted o a continued terror campaign?

- How do the stocks of firms with a significant share of their business activity in a region vulnerable to terrorism change with the evolution of a truce pact and its end?

Can a rational choice model of terrorist group tactics predict when suicide attacks are used?

- What can a theoretical model tell us about the impact of terrorism on output, investment, and consumption in the long run?

- Do the model's predictions correspond to evidence from an economy subject to continued terrorist attacks?

Over time, what are the consequences of transnational terrorism in terms of number of deaths?

- Have terrorist attacks become more threatening and lethal in recent years?

- Is there a cyclical pattern in the incidence of terrorism?

- What are the preferred targets?

- What are the best alternatives to deterrence in fighting terrorism?

- Do these strategies significantly dissuade potential terrorists?

- What do opinion polls tell us about the characteristic of supporters of terrorism?

-How does support change with education and personal income?
Paper

Becker, Gary S. and Yona Rubinstein (2004) "Fear and the Response to Terrorism: An Economic Analysis.” Mimeo.

Blomberg, S. Brock, Gregory Hess and Akila Weerapana (2004c) “An Economic Model of Terrorism." Conflict Management and Peace Science

Eldor, Rafi and Rafi Melnick (2004) "Financial Markets and Terrorism.” European Journal of Political Economy

Enders, W. and T. Sandler (2004) "What Do We Know about the Substitution Effect in

Transnational Terrorism?” In: A. Silke, ed. Researching

Terrorism: Trends,

Achievements, Failures.

Gupta, Sanjeev, Benedict Clements, Rina Bhattacharya and Shamit Chakravarti (2004)

"Fiscal Consequences of Armed Conflict and Terrorism in Lowand Middle-Income Countries." European Journal of Political Economy

Tavares, José (2004) “The Open Society Assesses Its Enemies: Shocks, Disasters and Terroris Attacks" Journal of Monetary Economics
Questions addressed

- How can fear and risk aversion explain individual responses to terror?

Does terror have an effect on the quality or the "quantity" of life?

- Can a model where terrorism is initiated by groups unhappy with their economic situation predict the occurrence of conflict?

-What does the choice between rebellion and terrorism depend on?

What is the reaction of the stock and foreign exchange markets to terrorist attacks in an economy subject to multiple terrorist attacks?

- Do stock and foreign exchange markets continue to perform efficiently?

- Does market liberalization help investors diversify and thus cope with terrorism?

- Is there a substitution effect among targets of transnational terrorists?

- What do you know of different approaches to combat terrorism?

- What are the fiscal effects of armed conflict and terrorism in low and middle-income countries?

How is increased government defense spending financed?

- What aggregate indicators are associated with a higher incidence of terrorist attacks?

- How does the impact of terrorist attacks on output compare with that of natural disasters and currency crises?

- Is the cost of a terrorist attack larger or smaller in the case of democracies? 


\section{Notes}

Fernanda Llussá is assistant professor at Faculdade de Ciências e Tecnologia, Universidade Nova de Lisboa and José Tavares is associate professor at the Faculdade de Economia at the same university and research affiliate at the Centre for Economic Policy Research (CEPR) in London. Tavares has benefited from support by the Fundação para a Ciência e Tecnologia through POCTI. Contact author: José Tavares at jtavares@fe.unl.pt.

1. For broader surveys on economics and terrorism see Laitin and Shapiro (forthcoming) on the motivations and organization of terrorists, Brück and Wickström (2004) and Enders and Sandler (forthcoming) on the consequences of terrorism and Llussà and Tavares (forthcoming) on the different issues and the research agenda. Brück (2006), Enders and Sandler (2006), and the forthcoming Keefer and Loayza are important comprehensive volumes.

2. Tavares (2004) shows that time series on terrorist attacks display a substantially higher standard deviation than similar series on natural disasters.

3. See Enders and Sandler (2002).

4. For discussion, see Enders and Sandler (1995; 2002), and Frey (2004).

5. As an example of an explanation for these counter-intuitive results, education can signal an individual's ability to commit, a necessary input for extreme actions. For an interesting exercise based on a different view, see Berman and Stepanyan (2004) who assesses the number of potentially "radical” Muslim women, based on fertility, low returns to education, and religious education.

6. The "demand" for suicide terrorists is the central issue in Wintrobe (2006) and Pape (2003).

7. Becker and Rubinstein (2004) argue that an exogenous shock to the probability of being harmed affects peoples' choice in two ways: a change in exposure to risk - the weights of "good" and "bad" states change - and in fear - in each state of nature, the utility level itself decreases in response to an increased probability of being harmed. Sunstein (2003) shows that individuals focus on the "badness" of the result rather than on the probability of occurrence. This so-called "probability neglect" results in fear that greatly exceeds the discounted harm.
8. The World Bank (2002, 2003) estimates the cost of the Palestinian-Israeli conflict for both contenders: while the cost to Israel is estimated at 4 percent of GDP, the Palestinian territories suffered a 50 percent decline in income per capita between 1994 and 2002. In addition, specific sectors such as tourism and trade have been especially hurt.

9. The contraction in trade may be in response to an increase to trade and transport costs, as argued in Organization for Economic Development and Cooperation (2002) and Lenain, et al. (2002).

10. Woo (2002) presents an analytical method to compute the risk of terrorism in actuarial terms. Lenain, et al. (2002) argue for a negative impact on the insurance industry.

11. There is also an as yet unsettled discussion on the appropriateness of government schemes that interfere with the insurance market, such as the Terrorism Risk Insurance Act (TRIA) in the United States. See, e.g., Kunreuther, et al. (2003); Chalk, et al. (2005); and Brown, et al. (2004).

12. This is true also of defense-related Israeli exports, which seem to benefit from a boom after the attacks.

13. Here we refer to the fiscal response to terrorist attacks and not the fiscal consequences of policy choices that are presented as a consequence of such attacks. As an example, the fiscal consequences of U.S. military involvement in Afghanistan and Iraq are certainly not trivial, but we consider such military involvement a policy choice in itself and not a necessary consequence of the September 2001 attacks.

14. See Frey (2004) for a discussion of the relative attractiveness of different counterterrorist policies.

15. Mickolus, et al. (1989) quote the statement by the IRA after a near-miss assassination attempt targeted at the United Kingdom's prime minister: “Today, we were unlucky. But remember we have only to be lucky once. You will have to be lucky always."

16. Frey (2004) lists a series of other costs, ranging from over-reliance on deterrence, including budgetary costs and political costs (in terms of possibly reduced support for counter-terrorism policy), exploitation by self-interested politicians to extend their stay in power, and reduced human rights and civil liberties. Deterrence also entails costs due to the response of terrorists, which gain in visibility and cohesion and substitute toward potentially deadlier means of attack. 
17. See Frey (2004).

References

Abadie, A. 2004. "Poverty, Political Freedom and the Roots of Terrorism”. NBER Working Paper No. 10859. Cambridge, MA: NBER.

Abadie, A and J. Gardeazabal. 2003. "The Economic Costs of Conflict: A Case Study of the Basque Country.” American Economic Review, Vol. 93, No. 1, pp. 113-132.

Abadie, A. and J. Gardeazabal. 2005. “Terrorism and the World Economy.” Mimeo. Harvard University.

Aziz, H. 1995. “Understanding Attacks on Tourists in Egypt.” Tourism Management, Vol. 16, No. 2, pp. 91-95.

Becker, G.S. and Y. Rubstein. 2004. "Fear and Response to Terrorism: An Economic Analysis.” Mimeo. University of Chicago.

Berman, E. 2003. "Hamas, Taliban and the Jewish Underground: An Economist's View of Radical Religious Militias.” NBER Working Paper No. 10004. Cambridge, MA: NBER.

Berman, E. and D. Laitin. 2005. "Hard Targets: Theory and Evidence on Suicide Attacks.” NBER Working Paper 11740. Cambridge, MA: NBER.

Berman, E and A. Stepanyan. 2004. "How Many Radical Islamists? Indirect Evidence from Five Countries.” Mimeo. University of California, San Diego.

Berrebi, C. and E.F. Klor. 2004. "On Terrorism and Electoral Outcomes: Theory and Evidence from the Israeli-Palestinian Conflict.” Industrial Relations Section, Working Paper Series. Princeton University.

Berrebi, C. and E.F. Klor. 2005. "The Impact of Terrorism Across Industries: An Empirical Study.” CEPR Discussion Paper No. 5360. London: Centre for Economic Policy Research.

Berrebi, C. 2003. "Evidence About the Link Between Education, Poverty and Terrorism Among Palestinians.” Industrial Relations Section, Working Paper Series. Princeton University.

Blomberg, S.B., G. Hess, and A. Orphanides. 2004a. "The Macroeconomic Consequences of Terrorism.” Journal of Monetary Economics, Vol. 51, No. 5, pp. 1007-1032.

Blomberg, S.B., G. Hess, and A. Weerapana. 2004b. "Economic Conditions and Terrorism.” European Journal of Political Economy, Vol. 20, No. 2, pp. 463-478.

Blomberg, S.B., G. Hess, and A. Weerapana. 2004c. “An Economic Model of Terrorism.” Conflict Management and Peace Science, Vol. 21, No. 1, pp. 17-28.

Bram, J., A. Haughwout, and J. Orr. 2002. "Has September 11 Affected New York City’s Growth Potential?” Federal Reserve Bank of New York Economic Policy Review, Vol. 8, No. 2, pp. 81-96.

Brauer, J., A. Gómez-Sorzano, S. Sethuraman. 2004. "Decomposing Violence: Political Murder in Colombia.” European Journal of Political Economy, Vol. 20,
No. 2, pp. 447-461.

Brown, J.R., J. David Cummins, C.M. Lewis, and R. Wei. 2004. “An Empirical Analysis of the Economic Impact of Federal Terrorism Reinsurance.” Journal of Monetary Economics, Vol. 51, No. 1, pp. 861-898.

Brück, T. ed. 2006. The Economic Analysis of Terrorism. London: Routledge.

Brück, T. and B.-A. Wickström. 2004. "The Economic Consequences of Terror: A Brief Survey.” Working Paper. School of Social Sciences and Cultural Studies, University of Sussex - Falmer.

Chalk, P., B. Hoffman, R. Reville, and A.-B. Kasupski. 2005. Trends in Terrorism: Threats to the United States and the Future of the Terrorism Risk Insurance Act. St. Monica, CA: Rand Center for Terrorism Risk Management Policy.

Charney, C. and N. Yakatan. 2005. “A New Beginning: Strategies for a More Fruitful Dialogue with the Muslim World.” CRS No. 7. New York: Council on Foreign Relations.

Chen, A.H. and T.F. Siems. 2004. "The Effects of Terrorism on Global Capital Markets.” European Journal of Political Economy, Vol. 20, No. 2, pp. 349-366.

Choudhry, T. 2003. "September 11 and Time-Varying Beta of United States Companies.” Mimeo. Bradford University School of Management.

Crenshaw, M. 1981. "The Causes of Terrorism.” Compartive Politics, Vol. 13, No. 4, pp. 379-399.

Cummins, J.D. and C.M. Lewis. 2003. “Catastrophic Events, Parameter Uncertainty and the Breakdown of Implicit Long-Term Contracting: The Case of Terrorism Insurance.” Journal of Risk and Uncertainty, Vol. 26, No. 2-3, pp. 153-178.

Downes-Le Guin, T. and B. Hoffman. 1993. "The Impact of Terrorism on Public Opinion, 1988 to 1989.” St. Monica, CA: RAND Corporation.

Drakos, K. 2004. "Terrorism-Induced Structural Shifts in Financial Risk: Airline Stocks in the Aftermath of the September 11th Terror Attacks.” European Journal of Political Economy, Vol. 20, No. 2, pp. 435-446.

Drakos, K. and A.M. Kutan. 2003. "Regional Effects of Terrorism on Tourism in Three Mediterranean Countries.” Journal of Conflict Resolution, Vol. 47, No. 5, pp. 621-641.

Eckstein, Z. and D. Tsiddon. 2004. "Macroeconomic Consequences of Terror: Theory and the Case of Israel.” Journal of Monetary Economics, Vol. 51, No. 1, pp. 9711002.

Eichenbaum, M. and J. D. M. Fisher. 2004. "Fiscal Policy in the Aftermath of 9/11." NBER Working Paper No. W10430. Cambridge, MA: NBER.

Eldor, R. and R. Melnick. 2004. "Financial Markets and Terrorism.” European Journal of Political Economy, Vol. 20, No. 2, pp. 367-386.

Enders, W. and T. Sandler. 1991. "Causality between Transnational Terrorism and Tourism: The Case of Spain.” Terrorism, Vol. 14, No. 1, pp. 49-58.

Enders, W. and T. Sandler. 1995. “Terrorism: Theory and Applications,” pp. 213-249 in K. Hartley and T. Sandler, eds. Handbook of Defense Economics, vol. 1. 
Amsterdam: Elsevier.

Enders, W. and T. Sandler. 1996. "Terrorism and Foreign Direct Investment in Spain and Greece.” Kyklos, Vol. 49, No. 3, pp. 331-352.

Enders, W. and T. Sandler. 2000. "Is Transnational Terrorism Becoming More Threatening?” Journal of Conflict Resolution, Vol. 44, pp. 307-332.

Enders, W. and T. Sandler. 2002. "Patterns of Transnational Terrorism, 1970-1999: Alternative Time-Series Estimates.” International Studies Quarterly, Vol. 46, No. 2, pp. 145-165.

Enders, W. and T. Sandler. 2004. "What Do We Know about the Substitution Effect in Transnational Terrorism?” in A. Silke, ed. Researching Terrorism: Trends, Achievements, Failures. Ilford, UK: Frank Cass.

Enders, W. and T. Sandler. 2006. The Political Economy of Terrorism. Cambridge, UK: Cambridge University Press.

Enders, W. and T. Sandler. Forthcoming. "Economic Consequences of Terrorism in Developed and Developing Countries: An Overview,” in Keefer and Loayza, eds. Terrorism and Economic Development. Cambridge, UK: Cambridge University Press.

Enders, W., T. Sandler, and G.F. Parise. 1992. “An Econometric Analysis of the Impact of Terrorism on Tourism.” Kyklos, Vol. 45, No. 4, pp. 531-554.

Enders, W., T. Sandler, and J. Cauley. 1990. "Assessing the Impact of TerroristThwarting Policies: An Intervention Time Series Approach.” Defense Economics, Vol. 2, pp. 1-18.

Epstein, G. and I.N. Gang. 2004. "Understanding the Development of Fundamentalism.” Discussion Paper No. 1227. Bonn: IZA (Institute for the Study of Labor).

Ferrero, M. 2005. “Martyrdom Contracts.” Mimeo. University of Eastern Piedmont.

Fielding, D. 2003a. "Counting the Cost of the Intifada: Consumption, Saving and Political Instability in Israel.” Public Choice, Vol. 116, No. 3-4, pp. 297-312.

Fielding, D. 2003b. "Modeling Political Instability and Economic Performance: Israeli Investment During the Intifada.” Economica, Vol. 70, No. 277, pp. 159186.

Fitzgerald, V. 2004. "Global Financial Information, Compliance Incentives and Terrorist Funding.” European Journal of Political Economy, Vol. 20, No. 2, pp. 387-401.

Fleischer, A. and S. Buccola. 2002. "War, Terror and the Tourism Market in Israel.” Applied Economics, Vol. 34, No. 11, pp. 1335-1343.

Frey, B.S. 2004. Dealing With Terrorism: Stick or Carrot? Cheltenham, UK: Elgar.

Frey, B.S. and S. Luechinger. 2003. "How to Fight Terrorism: Alternatives to Deterrence.” Defense and Peace Economics, Vol. 14, No. 4, pp. 237-249.

Frey, B.S. and S. Luechinger. 2004. "Decentralization as a Disincentive for Terror." European Journal of Political Economy, Vol. 20, No. 2, pp. 509-551.

Frey, B.S., S. Luechinger, and A. Stutzer. 2004. "Calculating Tragedy: Assessing the
Costs of Terrorism.” Working Paper 205. Institute for Empirical Research in Economics, University of Zurich.

Garfinkel, M.R. 2004. "Global Threats and the Domestic Struggle for Power.” European Journal of Political Economy, Vol. 20, No. 2, pp. 495-508.

Garoupa, N., J. Klick, and F. Parisi. 2005. "A Law and Economics Perspective on Terrorism.” Mimeo. Universidade Nova de Lisboa.

Glaeser, E.L. 2005. “The Political Economy of Hatred.” Quarterly Journal of Economics, Vol. 120, Issue 1, pp. 45 - 86.

Glaeser, E.L. and J. M. Shapiro. 2002. "Cities and Warfare: The Impact of Terrorism on Urban Form.” Journal of Urban Economics, Vol. 51, No. 2 pp. 205-224.

Gupta, S., B. Clements, R. Bhattacharya, and S. Chakravarti. 2004. "Fiscal Consequences of Armed Conflict and Terrorism in Low and Middle Income Countries.” European Journal of Political Economy, Vol. 20, No. 2, pp. 403-421.

Hardin, R. 1995. One for All: The Logic of Group Conflict. Princeton, NJ: Princeton University Press.

Harrigan, J. and P. Martin. 2002. "Terrorism and the Resilience of Cities.” Federal Reserve Bank of New York Economic Policy Review, Vol. 8, No. 2. pp. 97-116.

Hobjin, B. 2002. "What Will Homeland Security Cost?” Federal Reserve Bank of New York Economic Policy Review (November).

Im, E.I., J. Cauley, and T. Sandler. 1987. "Cycles and Substitutions in Terrorist Activities: A Spectral Approach.” Kyklos, Vol. 40, No. 2, pp. 238-255.

International Monetary Fund. 2001. "How Has September 11 Influenced the Global Economy,” chapter 2 in World Economic Outlook 2001. Washington, DC: International Monetary Fund.

Ito, H. and D. Lee. 2004. “Assessing the Impact of the September 11 Terrorist Attacks on US Airline Demand.” Journal of Economics and Business, Vol. 57, No. 1, pp. 75-95.

Keefer, P. and N. Loayza, eds. Forthcoming. Terrorism and Economic Development. Cambridge, UK: Cambridge University Press.

Krueger, A.B. and J. Maleckova. 2003.“Education, Poverty and Terrorism: Is There a Casual Connection?” Journal of Economic Perspectives, Vol. 17, No. 4, pp. 119-144.

Kunreuther, H., E. Michel-Kerjan, and B. Porter. 2003. “Assessing, Managing, and Financing Extreme Events: Dealing with Terrorism.” NBER Working Paper No. W10179. Cambridge, MA: NBER.

Lacker, J.M. 2004. "Payment System Disruptions and the Federal Reserve Following September 11, 2001.” Journal of Monetary Economics, Vol. 51, No. 5, pp. 935965.

Laitin, D. and J. Shapiro. Forthcoming. "The Political, Economic and Organizational Sources of Terrorism,” in Keefer and Loayza, eds. Terrorism and Economic Development. Cambridge, UK: Cambridge University Press.

Lapan, H.E. and T. Sandler. 1993. “Terrorism and Signalling.” European Journal of 
Political Economy, Vol. 9, pp. 383-397.

Lee, D.R. 1988. "Free Riding and Paid Riding in the Fight Against Terrorism." American Economic Review, Vol. 78, No. 2, pp. 22-26.

Lenain, P., M. Bonturi, and V. Koen. 2002. “The Economic Consequences of Terrorism.” Working Paper 334. Paris: OECD.

Llussà, F. and J. Tavares. Forthcoming. "Economics and Terrorism: What We Know, What We Should Know and the Data We Need," in Keefer and Loayza, eds. Terrorism and Economic Development. Cambridge, UK: Cambridge University Press.

Mickolus, E.F. 1980. Transnational Terrorism. Westport, CT: Greenwood Press.

Mickolus, E.F. 1982. "International Terrorism: Attributes of Terrorist Events, 19681977 (ITERATE 2).” Dunn Loring, VA: Vinyard Software.

Mickolus, E.F. and P. Fleming. 2003. "International Terrorism: Attributes of Terrorist Events (ITERATE), 1992-2002.” Dunn Loring, VA: Vinyard Software.

Mickolus, E.F., T. Sandler, J.M. Murdock, and P. Fleming. 1989. "International Terrorism: Attributes of Terrorist Events, 1978-1987 (ITERATE 3).” Dunn Loring, VA: Vinyard Software.

Mickolus, E.F., T. Sandler, J.M. Murdock, and P. Fleming. 1993. "International Terrorism: Attributes of Terrorist Events, 1988-1991 (ITERATE 4).” Dunn Loring, VA: Vinyard Software.

Mills, E.S. 2002. “Terrorism and U.S. Real Estate.” Journal of Urban Economics, Vol. 51, No. 2, pp. 198-204.

Mueller, D.C. 2004. "Rights and Citizenship in a World of Global Terrorism." European Journal of Political Economy, Vol. 20, No. 2, pp. 335-348.

Navarro, P. and A. Spencer. 2001. "September 2001: Assessing the Cost of Terrorism.” Milken Institute Review, Vol. 2, pp. 16-31.

Nitsch, V. and D. Schumacher. 2004. “Terrorism and International Trade: An Empirical Investigation.” European Journal of Political Economy, Vol. 20, No. 2, pp. 423-433.

Organization for Economic Development and Cooperation(OECD). 2002. The Impact of the Terrorist Attacks of 11 September 2001 on International Trading and Transport Activities. Paris: OECD Publications.

O’Brien, S.P. 1996. "Foreign Policy Crisis and the Resort to Terrorism: A Time Series Analysis of Conflict Linkages.” Journal of Conflict Resolution, Vol. 40, No. 2, pp. 320-335.

Pape, R.A. 2003. “The Strategic Logic of Suicide Terrorism.” American Political Science Review, Vol. 97, No. 3, pp. 343-361.

Rossi-Hansberg, E. 2003. “Cities Under Stress.” Journal of Monetary Economics, Vol. 51, No. 5, pp. 903-927.

Sandler, T. and W. Enders. 2004. “An Economic Perspective on Transnational Terrorism.” European Journal of Political Economy, Vol. 20, No. 2, pp. 301-316. Schelling, T.C. 1991. "What Purposes Can ‘International Terrorism’ Serve?” pp. 18-
32 in R.G. Frey and C. W. Morris, eds. Violence, Terrorism and Justice. Cambridge, UK: Cambridge University Press.

Shambaugh, G. and W. Josiger. 2004. "Public Prudence, the Policy Salience of Terrorism and Presidential Approval Following Terrorist Incidents.” Annual Joint Conference of the International Security and Arms Control Section of the American Political Science.

Sloboda, B.W. 2003. "Assessing the Effects of Terrorism on Tourism by Use of Time Series Methods.” Tourism Economics, Vol. 9, No. 2, pp. 179-190.

Sunstein, C.R. 2003. “Terrorism and Probability Neglect.” Journal of Risk and Uncertainty, Vol. 26, No. 2-3, pp. 121-136.

Tavares, J.. 2004. "The Open Society Assesses Its Enemies: Shocks, Disasters and Terrorist Attacks.” Journal of Monetary Economics, Vol. 51, No. 5, pp. 1039-1070.

Viscusi, W.K. and R.J. Zeckhauser. 2003. "Sacrificing Civil Liberties to Reduce Terrorism Risks.” Journal of Risk and Uncertainty, Vol. 26, No. 2-3, pp. 99-120.

Walkenhorst, P. and N. Dihel. 2002. "Trade Impacts of the Terrorist Attacks of 11 September 2001: A Quantitative Assessment.” Conference paper. Economic Consequences of Global Terrorism. German Institute for Economic Research (DIW Berlin), June 14-15.

Wildasin, D.E. 2002. "Local Public Finance in the Aftermath of September 11." Journal of Urban Economics, Vol. 51, No. 2, pp. 225-237.

Wintrobe, R. 2001. "Can Suicide Bombers Be Rational?” Mimeo. University of Western Ontario.

Wintrobe, R. 2006. Rational Extremism. Oxford, UK: Oxford University Press.

Woo, G. 2002. “Quantifying Insurance Terrorism Risk.” Working Paper. Cambridge, MA: National Bureau of Economic Research.

World Bank. 2002. Fifteen Months Intifada, Closures and Palestinian Economic Crisis: An Assessment. Washington, DC: World Bank.

World Bank. 2003. Two Years of Intifada, Closures and Palestinian Economic Crisis: An Assessment. Washington, DC: World Bank. 